\title{
Adsorption Technique for Drainage Water Treatment
}

\author{
May Samir Saleh ${ }^{1, *}$ and Huda T. Hamad ${ }^{2}$ \\ ${ }^{1}$ Water Resource Engineering Dpt. College of Engineering, Mustansiriyah University, Iraq - Baghdad, maysamirsaleh@yahoo.com \\ ${ }^{2}$ Water Resource Engineering Dpt. College of Engineering, Mustansiriyah University, Iraq - Baghdad, hu_da2005@ yahoo.com
}

\begin{abstract}
This study evaluated the suitability of an adsorption technique in drainage water treatment for irrigation purposes. The water samples for this study were sourced from different spots of Al-MASAB AL A'AM river. Three different locations (Latifia, Yusufiyah, and Swerah area) were considered in this study. Several studies have reported the use of activated carbon and ion exchangers for water treatment. In this work, a cheap alternative bio-filtration media (activated carbon derived from Apricot stones (ASAC)) was used. Several parameters are required in this technique for various estimations; such parameters include the chemical and physical properties of the water samples (like the $\mathrm{pH}$, ionic concentration, electrical conductivity (EC), and total dissolved solids (TDS). The Freundlich equations was also applied to study the chemical adsorption process using ASAC. Also calculated were the adsorption constant $(\mathrm{k})$ and the number of adsorbents (n). From the results of this study, the applied process was suitable for the removal of $\mathrm{Ca}^{+2}$, $\mathrm{Mg}^{+2}$ and $\mathrm{CO}_{3}^{-2}$ ions from the sampled water.
\end{abstract}

\section{Introduction}

The increase in the global population, as well as the improvements in the peoples' way of life, have resulted in an increase in the demand for water. With the adoption of irrigation as a standard agricultural practice in areas with short annual rainfall, the agricultural demands for water have also increased tremendously. The commercialization of agriculture has been restricted in many countries due to water scarcity. The reutilization of drainage water for agricultural purposes can improve farm productivity and contribute to aquifer recharge, thereby saving the cost of drainage water management and the value of the reclaimed fresh water. However, there may be some environmental hazards associated with drainage water irrigation owing to the presence of several pollutants like heavy metals and pathogens in the drainage water. Serious health challenges could emerge from the use of low-quality water for agricultural purposes; it could also result in soil degradation and decreased crop yield $[1,2]$. Many classifications have been proposed regarding water suitability for irrigation. The classification presented by Richard [3] is based on the relationship between sodium absorption ratio (SAR) and electrical conductivity (EC), while Ayers \& Westcot [4] presented a classification that depended on the five groups that represent the hydro-chemical changes, including the salinity, cations and anions concentrations measured in (epm), nutrients measured in (ppm), and the influence of other miscellaneous materials. The classification presented by Don [5] depended on EC, TDS, SAR, and Na concentration [6].
Different natural raw materials can be used to prepare activated carbons. Among the characteristics of activated carbons is high mechanical strength. Activated carbons can be produced from the shells of coconut and other nuts [7] via a chemical activation process. During the preparation of activated carbon from shells, $\mathrm{NaOH}$ is used as the activation agent at a high temperature of $700^{\circ} \mathrm{C}$ [8]. Activated carbon can also be produced from fruit kernels or olive pits [9] via the carbonization of the olive fruit or seeds. Other sources of activated carbon include almond shells via carbonization in N2 stream, followed by activation in $\mathrm{CO}_{2}$ stream [10]; plum kernels via carbonization, followed by $\mathrm{CO}_{2}$ activation [11]; macadamia nuts via high temperature activation at $900^{\circ} \mathrm{C}$, followed by a mixture of water, air, and $\mathrm{CO}_{2}$ streams [12]. Activated carbon can also be produced from almond and olive shells via several methods, such as carbonization in $\mathrm{N}_{2}$ stream followed by $\mathrm{CO}_{2}$ activation, direct activation in $\mathrm{CO}_{2}$, as well as dry air treatment at $300^{\circ} \mathrm{C}$ followed by $\mathrm{CO}_{2}$ activation [13].

This study investigated the adsorption characteristics of drainage water using ASAC as adsorbent. During the study, the adsorption isotherms and thermodynamics of ASAC were determined, while the correlation between the isotherm models and the experimental data was determined by fitting the equilibrium data to Langmuir and Freundlich equations. The adsorption mechanism was determined by calculating the thermodynamic parameters. Also studied was the influence of certain parameters (such as the initial concentration of dye, dosage, temperature, and $\mathrm{pH}$ ) on dye removal. 


\section{Study Area}

One of the major developmental projects in Iraq is the Al-Masab Al-Aamis project due to its importance in saline water transportation from the reclamation of agricultural land in the center and southern Iraq. This transportation is mediated through an interconnected network of a secondary and major trocar which eventually flow into the general estuary. Saline water and chemical fertilizer residues used in agriculture are also transported to the Arabian Gulf via the Shatt al Basra. Three stations have been chosen in this study: Station No. 1 is AL-Yusfiya city, south of capital Baghdad, about $25 \mathrm{~km}$ south; Station No. 2 is $\mathrm{Al}$ Latifiya city, about $25 \mathrm{~km}$ east from station No. 1, and $35 \mathrm{~km}$ south of Baghdad city; and Station No. 3 at Suwayrah city, about $135 \mathrm{~km}$ north of Kut governorate and $55 \mathrm{~km}$ south of Baghdad city. The latitude and longitude for these stations are $\left(33.033333^{\circ}\right) \mathrm{N}$ and $\left(44.166667^{\circ}\right) \mathrm{E},\left(33.079408^{\circ}\right) \mathrm{N}$ and (44.251662) E, and $\left(32.925267^{\circ}\right) \mathrm{N}$ and $\left(44.770958^{\circ}\right) \mathrm{E}$, respectively. Figure Ishowed an aerial view (Google Earth) of the locations of the selected stations.

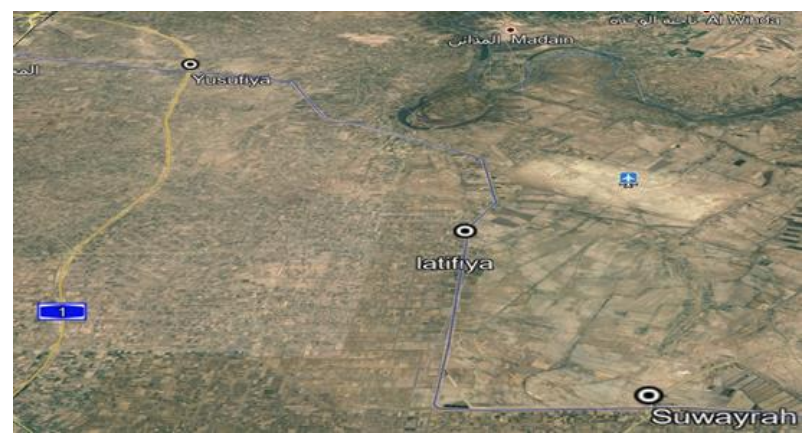

Figure 1. Google Earth location of the selected stations

\section{Experimental}

\subsection{Preparation of activated carbon from waste apricot stones}

To prepare the activated carbons, apricot stones were collected from Baghdad city, crushed and sieved to a particle size range of $2.5 \times 0.75 \mathrm{~mm}$ before activation. Chemical activation of the material using $\mathrm{H}_{2} \mathrm{SO}_{4}$ at moderate temperatures conferred the material with a high degree of micro-porosity and high surface area. A mixture of the material with conc. $\mathrm{H}_{2} \mathrm{SO}_{4}(2: 1$ wt ratio) was made and heated in an oven at $600^{\circ} \mathrm{C}$ for $1.5 \mathrm{~h}$. Then, the sample was removed from the oven and cooled to room temperature, before being washed with distilled water and later soaked in $\mathrm{NaHCO}_{3}$ solution (1\%) to get rid of the remaining acid. The washing process was continued in distilled water until the activated carbon reaches $\mathrm{pH}$ 7. The activated carbon was dried for $5 \mathrm{~h}$ at $100^{\circ} \mathrm{C}$ and sorted into the desired size $(\leq 75 \mu \mathrm{m})[14]$.

\subsection{Water sample collection}

The water samples were taken from three positions (Latifia, Yusufiyah, and Swerah area) of the Al-MASAB AL A'AM river. Three water samples were taking from each position.

\subsection{Adsorption studies and measurements}

Several experimental parameters were studied for effects on dye removal. The studied parameters include the initial concentration of dye $\left(5-15 \mathrm{mgL}^{-1}\right)$, dosage of the adsorbent (5-50 mg/100 mL), $\mathrm{pH} \mathrm{(5-9),} \mathrm{temperature}$ $\left(10-40^{\circ} \mathrm{C}\right)$, and particle size $\leq 75 \mu \mathrm{m}$. The test tubes were stationed in a shaker and allowed to agitate progressively for $0.5 \mathrm{~h}$ at $30^{\circ} \mathrm{C}$ and agitation rate of at $250 \mathrm{rpm}$ to obtain a stable concentration. The mixtures were then filtrated through Whatman No 4 filter paper. Equation 1 was used to determine the retained concentration of the solute (qe/mgg- $\left.{ }^{1}\right)$ in the adsorbent phase [15]:

$$
q_{e}=\frac{\left(C_{0}-C_{e}\right) V}{W_{s}}
$$

where

$\mathrm{Co}=$ the initial concentration of the solute $(\mathrm{mg} / \mathrm{L})$

$\mathrm{Ce}=$ the final concentration of the solute at equilibrium $(\mathrm{mg} / \mathrm{L})$

$V=$ volume of the solution

$W \mathrm{~s}=$ the adsorbents' mass $(\mathrm{g})$.

Equation 2 was used to calculate the percentage of removal efficiency.

$$
R(\%)=\frac{\left(C_{0}-c_{\varepsilon}\right)}{c_{0}} * 100
$$

\section{Results and Discussion}

\subsection{Chemical measurements before adsorption}

The untreated samples were chemically analyzed for the presence of different elements which can affect the quality of water for irrigation purpose. The samples were analyzed for the following elements: $\mathrm{Ca}^{+2}, \mathrm{Mg}^{+2}, \mathrm{~K}^{+}$, $\mathrm{Na}^{+}, \mathrm{Cl}^{-}, \mathrm{CO}_{3}^{-2}, \mathrm{SAR}$, and TDS. The results are presented in Table 1. a and b.

SAR was calculated using the following equation [16]:

$$
S A R=\left(\mathrm{Na}^{+} /\left(\frac{\mathrm{Ca}^{+2}+\mathrm{Mg}^{+2}}{2}\right)^{\wedge} 0.5\right.
$$


Table 1. a.Chemical composition of the samples before adsorption

\begin{tabular}{|c|c|c|c|c|c|c|}
\hline $\begin{array}{c}\text { Station } \\
\text { No. }\end{array}$ & $\begin{array}{l}\text { Sample } \\
\text { No. }\end{array}$ & $\mathrm{pH}$ & $\begin{array}{c}\mathrm{Ca}^{+2} \\
\mathrm{ppm}\end{array}$ & $\begin{array}{c}\mathrm{Mg}^{+2} \\
\mathrm{ppm}\end{array}$ & $\begin{array}{c}\mathrm{CO}_{z}^{-2} \\
\mathrm{ppm}\end{array}$ & $\begin{array}{c}\mathrm{Cl}^{-1} \\
\mathrm{ppm}\end{array}$ \\
\hline \multirow{3}{*}{1} & $1-1$ & 8.54 & 41.54 & 33.76 & 66.34 & 7.56 \\
\cline { 2 - 7 } & $1-2$ & 8.44 & 40.98 & 31.45 & 63.44 & 7.12 \\
\cline { 2 - 7 } & $1-3$ & 8.14 & 40.66 & 30.66 & 60.43 & 6.76 \\
\hline \multirow{3}{*}{2} & $2-1$ & 8.77 & 33.66 & 27.66 & 55.34 & 4.54 \\
\cline { 2 - 7 } & $2-2$ & 8.67 & 31.55 & 25.43 & 50.12 & 4.11 \\
\cline { 2 - 7 } & $2-3$ & 8.49 & 30.66 & 24.53 & 49.54 & 3.88 \\
\hline \multirow{3}{*}{3} & $3-1$ & 8.66 & 24.56 & 19.76 & 38.54 & 3.21 \\
\cline { 2 - 7 } & $3-2$ & 8.73 & 23.65 & 19.11 & 36.76 & 3.10 \\
\cline { 2 - 7 } & $3-3$ & 8.65 & 22.77 & 18.43 & 43.12 & 2.98 \\
\hline
\end{tabular}

Table 1. b.Chemical composition of the samples before adsorption

\begin{tabular}{|c|c|c|c|c|c|}
\hline $\begin{array}{c}\text { Station } \\
\text { No. }\end{array}$ & $\begin{array}{c}\text { Sample } \\
\text { No. }\end{array}$ & $\begin{array}{c}\mathrm{K}^{+} \\
\mathrm{ppm}\end{array}$ & $\begin{array}{c}\mathrm{Na}^{+} \\
\mathrm{ppm}\end{array}$ & SAR & $\mathrm{TDS}$ \\
\hline \multirow{4}{*}{1} & $1-1$ & 15.43 & 198 & 32.26 & 4554 \\
\cline { 2 - 6 } & $1-2$ & 14.87 & 175 & 20.56 & 4387 \\
\cline { 2 - 6 } & $1-3$ & 14.22 & 166 & 19.65 & 4123 \\
\hline \multirow{4}{*}{2} & $2-1$ & 16.44 & 150 & 19.15 & 3842 \\
\cline { 2 - 6 } & $2-2$ & 13.55 & 145 & 19.20 & 3756 \\
\cline { 2 - 6 } & $2-3$ & 13.21 & 140 & 18.84 & 3723 \\
\hline \multirow{3}{*}{3} & $3-1$ & 11.76 & 137 & 20.57 & 3432 \\
\cline { 2 - 6 } & $3-2$ & 9.65 & 129 & 19.72 & 3389 \\
\cline { 2 - 6 } & $3-3$ & 9.12 & 120 & 18.69 & 3278 \\
\hline
\end{tabular}

\subsection{Chemical measurements after adsorption}

The concentrations of all the ions were re-evaluated after adsorption. It was found that the concentration of all the ions was lower than before adsorption as shown in Table 2. a and b.

Table 2. a.Chemical composition of the samples after adsorption

\begin{tabular}{|c|c|c|c|c|c|c|}
\hline $\begin{array}{c}\text { Station } \\
\text { No. }\end{array}$ & $\begin{array}{l}\text { Sample } \\
\text { No. }\end{array}$ & $\mathrm{pH}$ & $\begin{array}{c}\mathrm{Ca}^{+2} \\
\mathrm{ppm}\end{array}$ & $\begin{array}{c}\mathrm{Mg}^{+2} \\
\mathrm{ppm}\end{array}$ & $\begin{array}{c}\mathrm{CO}_{z}^{-2} \\
\mathrm{ppm}\end{array}$ & $\begin{array}{c}\mathrm{Cl}^{-1} \\
\mathrm{ppm}\end{array}$ \\
\hline \multirow{3}{*}{1} & $1-1$ & 7.33 & 29.43 & 23.26 & 46.34 & 5.36 \\
\cline { 2 - 7 } & $1-2$ & 7.29 & 27.65 & 21.65 & 43.44 & 5.22 \\
\cline { 2 - 7 } & $1-3$ & 7.23 & 23.76 & 20.56 & 40.43 & 4.86 \\
\hline \multirow{3}{*}{2} & $2-1$ & 7.37 & 21.16 & 19.54 & 33.34 & 3.64 \\
\cline { 2 - 7 } & $2-2$ & 7.40 & 20.35 & 18.65 & 32.12 & 3.21 \\
\cline { 2 - 7 } & $2-3$ & 7.42 & 19.96 & 17.65 & 31.34 & 2.78 \\
\hline \multirow{3}{*}{3} & $3-1$ & 7.22 & 18.44 & 13.36 & 22.44 & 2.81 \\
\cline { 2 - 7 } & $3-2$ & 7.29 & 16.43 & 12.91 & 21.46 & 2.13 \\
\cline { 2 - 7 } & $3-3$ & 7.34 & 14.54 & 11.83 & 20.72 & 1.68 \\
\hline
\end{tabular}

Table 2. b.Chemical composition of the samples after adsorption

\begin{tabular}{|c|c|c|c|c|c|}
\hline $\begin{array}{c}\text { Station } \\
\text { No. }\end{array}$ & $\begin{array}{c}\text { Sample } \\
\text { No. }\end{array}$ & $\begin{array}{c}\mathrm{K}^{+} \\
\text {ppm }\end{array}$ & $\begin{array}{c}\mathrm{Na}^{+} \\
\mathrm{ppm}\end{array}$ & SAR & TDS \\
\hline \multirow{3}{*}{1} & $1-1$ & 11.43 & 98 & 19.09 & 4254 \\
\cline { 2 - 6 } & $1-2$ & 10.87 & 90 & 12.81 & 4187 \\
\cline { 2 - 6 } & $1-3$ & 10.22 & 87 & 13.06 & 3895 \\
\hline \multirow{2}{*}{2} & $2-1$ & 9.44 & 77 & 12.06 & 3765 \\
\cline { 2 - 6 } & $2-2$ & 9.15 & 71 & 11.36 & 3556 \\
\hline
\end{tabular}

\begin{tabular}{|l|l|l|l|l|l|}
\hline & $2-3$ & 9.01 & 70 & 11.41 & 3463 \\
\hline \multirow{3}{*}{3} & $3-1$ & 8.65 & 58 & 10.28 & 3312 \\
\cline { 2 - 6 } & $3-2$ & 8.22 & 55 & 10.15 & 3259 \\
\cline { 2 - 6 } & $3-3$ & 7.62 & 53 & 10.32 & 3175 \\
\hline
\end{tabular}

By observing the values shown in Tables 1 and 2, it was noticed that all the values of the chemical measurements after adsorption were lower than before adsorption at different rates.

- Note that the values of $\mathrm{pH}$ between 8.14-8.73 and 7.237.42 before and after adsorption respectively, indicated that the water bases are mild to neutral. The permissible limits for $\mathrm{pH}$ values for irrigation water are between 68.5 (FAO, 1985).

- The results of SAR before and after adsorption ranged from 18.69-32.26 to 10.32-19.08 ppm. According to the specification (FAO,1994), if the value of SAR is greater than $9 \mathrm{ppm}$, the irrigation water is suitable for irrigating salinity-resistant plants grown in good permeability and drainage land with the addition of washing water from $20-25 \%$ of water consumption for plants.

- The values of TDS ranged between 4554 and 3173 before and after adsorption, respectively. As per specification (FOW,1985), the allowable limit for irrigation is between $0-2000 \mathrm{ppm}$. This means that the irrigation water is not suitable for irrigation.

- Adsorption using apricot stones activated carbon (ASAC) was observed to be more effective for ions $\left(\mathrm{Ca}^{+2}, \mathrm{Mg}^{+2}\right.$, and $\left.\mathrm{CO}_{3}^{-2}\right)$. The adsorption value for $\mathrm{Ca}^{+2}$ was $75.3 \%$ while the percentage adsorption for $\mathrm{Mg}^{+2}$ and $\mathrm{CO}_{3}^{-2}$ were $65.4 \%$ and $56.8 \%$ respectively, as shown in Figures 2-4. The other elements had little adsorption values of $<20 \%$.

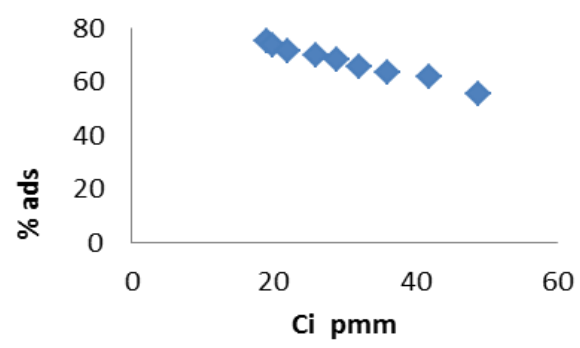

Figure 2. The relationship between concentration and adsorption ratio for $\mathrm{Ca}^{+2}$.

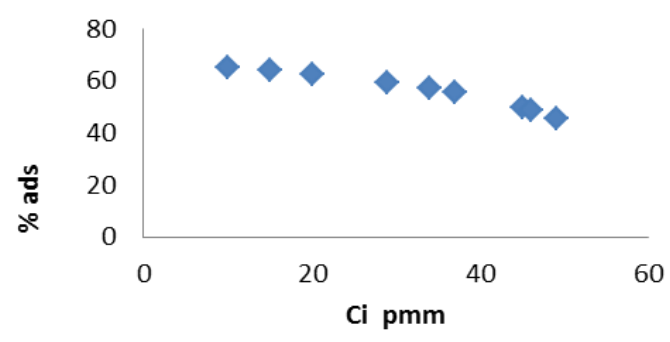

Figure 3. The relationship between concentration and adsorption ratio for $\mathrm{Mg}^{+2}$. 


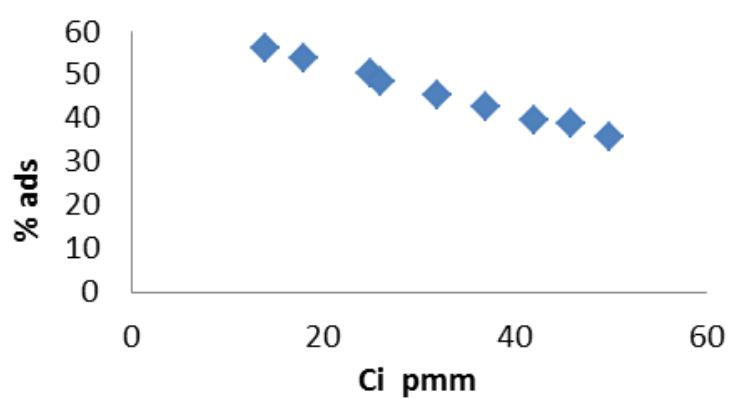

Figure 4. The relationship between concentration and adsorption ratio for $\mathrm{CO}_{3}^{-2}$

\subsection{Adsorption isotherms}

Freundlich isotherm model was used to study the adsorption isotherms. Equation.4 assumes physicochemical adsorption on heterogeneous surfaces.

$$
\log q_{e}=\log \log K_{F}+\frac{1}{n \log \log C_{e}}
$$

Where

$K_{F}$ and $(1 / \mathrm{n})=$ Freundlich adsorption isotherm constants, indicating the extent of adsorption and the adsorption intensity, respectively [17].

The high correlation coefficient value indicates the suitability of the Freundlich isotherm to fit with the equilibrium data as shown in Figures 5-7.

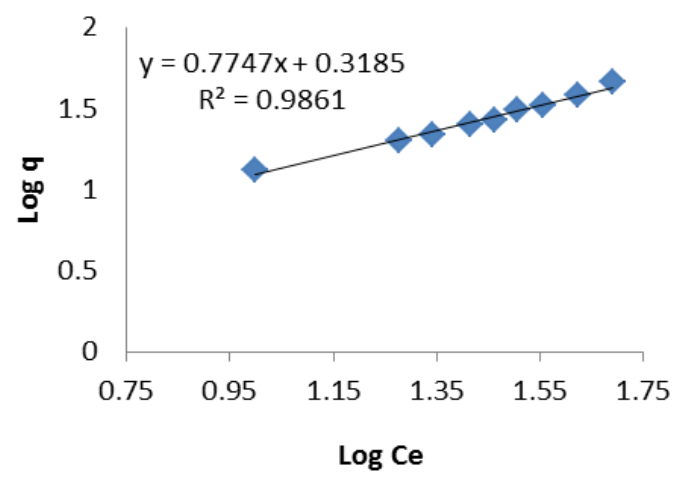

Figure 5. Freundlich adsorption isotherm for $\mathrm{Ca}^{+2}$.

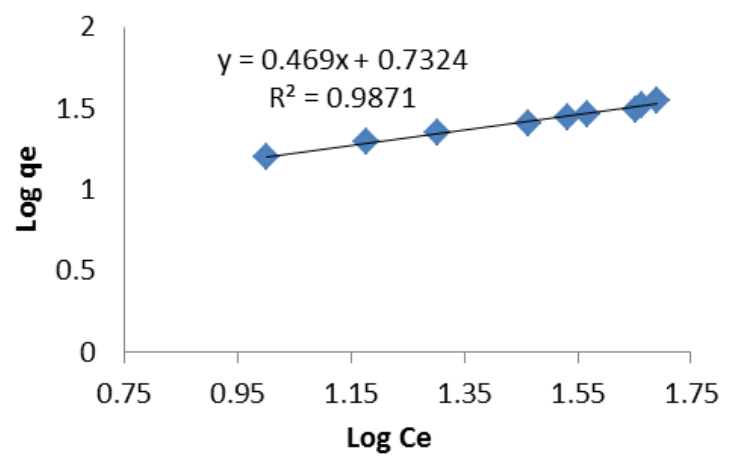

Figure 6. Freundlich adsorption isotherm for $\mathrm{Mg}^{+2}$.

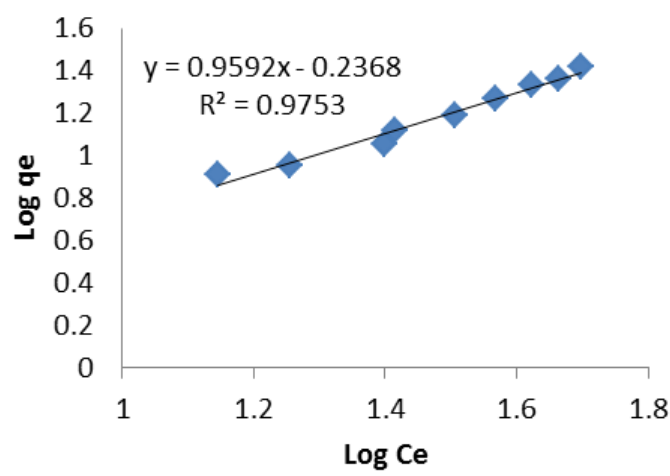

Figure 7. Freundlich adsorption isotherm for $\mathrm{CO}_{3}^{-2}$.

Table 3 presented the isotherm parameters derived from the intercept and slope of the plots.

Ions $K_{F} \quad \mathrm{n} \quad \mathrm{R}^{2}$

$\mathrm{Ca}^{+2}-2.080 .9861$

$\begin{array}{llll}\mathrm{Mg}^{+2} & 5.4 & 2.132 & 0.9871\end{array}$

$\begin{array}{llll}\mathrm{CO}_{3}^{-2} & 1.043 & 1.725 & 0.975\end{array}$

\section{Conclusion and Recommandation}

The outcome of this study showed that (ASAC) could be used as an adsorbent for the removal of $\mathrm{Ca}^{+2}, \mathrm{Mg}^{+2}$ and $\mathrm{CO}_{3}^{-2}$ ions from the sampled water. The results also showed that the Freundlich isotherm equation provided the best fit for the experimental data. For future studies use of a cheap alternative bio-filtration medium activated carbon from date seeds (ADS) as an adsorbent for technique in drainage water treatment for irrigation purposes.

The acknowledgments: The author would like to thank Mustansiriyah University (www.uomustansiriyah.edu.iq), Baghdad, Iraq, for its support in the present work. The author also acknowledge the faculty and staff of the Sanatery Laboratory, Environmental Engineering Department, Mustansiriyah University.

\section{References}

1. S. Turkar, D. Bharti and G. Gaikwad " Various method involved in waste water treatment to control water pollution", Journal of Chemical and Pharmaceutical Research, 3(2):58-65, (2011).

2. S. Donald, "Determining water suitability for irrigation", Int'l Soil Sci. Soc. Conf. Proceedings. 1018:1-6. NA (1998).

3. C.Maia and K.Rodrigues,"Proposal for an Index to Classify Irrigation water quality: a case study in 
northeastern Brazil", Revista Brasileira de Ciência do Solo, 36(3) (2012) https://doi.org/10.1590/S0100-06832012000300013

4. A.Meireles, E. Andrade, L.Chaves, H.Frischkorn and L. Crisostomo, "A new proposal of the classification of irrigation water", Revista Ciencia A gronomica, 41(3):349-357 (2010),. DOI: $\underline{10.1590 / \mathrm{S} 1806-66902010000300005}$

5. M. Feizi, M. Hajabbasi and B.Mostafazadeh-Fard "Saline irrigation water management strategies for better yield of safflower (carthamus tinctoriuos L.) in an arid region" Australian Journal of Crop Science, 4(6):408-414(2010).

6. M. Al-Dabbas, S. Abdul Razzaq, "The Use of Water Quality Index Technique to Assess Ground Water and Drainage Water for Irrigation in Alyusufyiah Area - Baghdad Governorate -Central Iraq", 58(4): 1849-1855 (2017). DOI: 10.24996/ ijs.2017.58.4A.9

7. P. Branton, , and R. Bradley.. "Effects of active carbon pore size distributions on adsorption of toxic organic compounds". Adsorption, 17: 293301(2011). http://dx.doi.org/10.1007/s10450-0109284-4

8. A. Linares-Solano, M. Lillo-Rodenas, J. Marco Lozar,, M. Kunowsky and A. Romero Anaya "NaOH and $\mathrm{KOH}$ for preparing activated carbons used in energy and environmental applications" International Journal of Energy, Environment and Economics. 20(4): 59-91 (2012).

9. W. Buah., J. Kuma, "Properties of Activated Carbon Prepared from Coconut Shells in Ghana" Ghana Mining Journal, 13: 51 - 55, (2012)

10. F. Rodrigues-Reinoso, D. Lopez-Gonzales and C.Berenguerm,. "Activated carbons from almond shells II. Caracterization of the pore structure"22(1):13-18(1984). http://dx.doi.org/10.1016/0008-6223(84)90128-3

11. F. Rodriguez-Reinoso, J. Martin-Martinez, MolinoSabio, I. Perez-Lleodo, and C. Prado-Burguete, "A.. Comparison of the porous texture of two $\mathrm{CO} 2$ activated botanic materials". Carbon 23(1): 19-24 (1985). http://dx.doi.org/10.1016/0008$\underline{6223(85) 90191-5}$

12. E. Sato, (1986). Activated carbon. USA Patent № 4616001 .

13. M. Satayev, R. Alibekov, L. Satayeva, O. Baiysbay and B. Mutaliyeva, "Characteristics of Activated Carbons Prepared from Apricot Kernel Shells by Mechanical, Chemical and Thermal ,Activations" Canadian of Science and Education 9(6), 2015

14. S. Khaleefa, H. Hamad, "Textile Dye Removal by Activated Date Seeds", Fourth International
Scientific Conference on Environment and

Sustainable Development (4th ISCESD), Egypt,

Cairo, 37(2), Part C., 2019, DOI:

http://dx.doi.org/10.30684/etj.37.2C.7

15. R. Alibekov, M. Auezov', "State University, "Characteristics of Activated Carbons Prepared from Apricot Kernel Shells by Mechanical, Chemical and Thermal Activations", Modern Applied Science 9(6), (2015).

http://dx.doi.org/10.5539/mas.v9n6p104

16. O. Mohammed, M. Hassan, 'Evaluation of Drainage Water Quality for Irrigation By Integration Between Irrigation water Quality Index and GIS', 3(4): 24-32 (2015).

17. H. Hamad, " Removal of Phenol and Inorganic Metals from Wastewater Using Activated Ceramic", Journal of King Saud University, published online, 2020, DOI: 10.1016/j.jksues.2020.04.006

18. K. Bakhair, M. Ashraf, " field accumulation risks of heavy metals in soil and vegetable crop irrigated with sewage water in western region of Saudi Arabia,Saudi" Saudi Journal of Biological Sciences, 23, Issue1, pp .s32-s44 (2016). 